The report makes it clear that these increases can only be achieved by additional storage, controlled use, and a policy of integrated river basin development. The authors reject the extensive use of conventional storage reservoirs and pumped storage schemes and come down in favour of regulating reservoirs, with which, it is maintained, an additional 250 million gallons per day could be guaranteed, an adequate flow in the Severn preserved at all times, much agricultural and urban land protected from flooding, and up to 64,000 acres irrigated in times of drought. W. G. V. BALCHIN
1 Ministry of Housing and Local Government, and Scottish Office. 'he Surface Water Year-Book of Great Britain, 1958-59: Hydrometric Statistics for British Rivers, together with related Rainfalls, for the year ended 30th September, 1959. Pp. xiv +92. (London: H.M. Stationery Office, 1960.) 17s. 6d. net.

2 Central Advisory Water Committee. Sub-Committee on the Growing Demand for Water. Second Report. Pp. 5. (London: H.M. Stationery Office, 1960.) 6d. net.

- Ministry of Housing and Local Government. River Great Ouse Basin: Hydrological Survey (Hydrometric Area No. 33). Pp. $100+9$ folding maps. (London: H.M. Stationery Office, 1960.) 128. $6 d$.

- Ministry of Housing and Local Government. River Severn Basin : Hydrological Survey (Hydrometric Area No. 54 ). Pp. iv +134.
(London: H.M. Stationery Office, 1960.) 178. 6d. net.

\title{
HYGIENE AND PLANT PROTECTION
}

$\mathrm{T}$ THE chemical means of plant protection and problems of hygiene have been reviewed by L. I. Medved, director of the Kiev Institute of Labour Hygiene and Occupational Diseases, in a recent issue of Impact of Science on Society (10, No. 4, 1960).

The systematio fight against pests and diseases of cultivated plants is not only of great economic importance, but is also socially significant. It has been calculated that the loss of food and technical crops on the farms of the United States due to pests, fungoid diseases and weeds amounts to about 11,000 million dollars a year. Similarly it has been shown that implementation of measures for the protection of plants against pests, diseases and weeds would make an additional quantity of agricultural produce, valued at about 54 billion roubles, available in the U.S.S.R. While the quantity of pesticides produced and employed in agriculture by either of these two countries is considered greater than by any other, and, if they possess enormous reserves for increasing agricultural produce as a result of further use of pesticides, the same opportunities exist in other countries.

The beneficial aspect of the use of poisonous chemicals in agriculture is evident, but the social effects should not be overlooked. All, or almost all, the chemicals employed are biologically active, and in some cases are potentially poisonous for human beings. Investigations by Soviet scientists have shown that the prolonged action on the human organism of various chemical substances, even in insignificant quantities, may lead to a fall in the reactivity of the organism and to a rise in susceptibility to other diseases. In such cases, acute and chronic intoxication does not occur, but a general high level of morbidity is noted.

The problem of the carcinogenic effect of certain chemicals requires special attention. There are indications that carbolineum and its preparations, employed in a number of countries, contain a carcino. genic impurity (benzpyrene). There have been reports on the carcinogenic properties of iso-propylic ether of 3-chloro-phenylcarbamic acid, applied as herbicides in a number of countries. Concern is felt in the United States about the carcinogenic properties of certain organochloric insecticides.

The danger of chemicals to public health does not lie only in the possibility of accidents (acute intoxi- cations). The chief danger to the health of the population lies in the prolonged chronic action of certain preparations inducing pathological states which are not ordinarily diagnosed as intoxication. Considerable data have been presented by American investigators on the rise in the incidence of diseases of the liver and gastro-intestinal tract, and of cardiovascular and nervous diseases among the population of the United States and a number of other countries, as a result of the extensive use of DDT and other organochloric compounds.

The duty of toxicology as the science of the toxic properties of chemical substances is not only to determine the lethal doses of one substance or another, but also to ascertain the possibilities of its chronic effect on the human organism over a prolonged period of intake in small quantities. A preparation which is widespread throughout the world, like DDT, has only a slightly toxic effect on the organism in a single dose, and the probability of poisoning with a lethal outcome is insignificant. When taken into the organism in various ways, however, DDT accumulates in the fatty tissues and is retained in them for a long time. Even in slight quantities, DDT acts very slowly, but destructively, on the organism. The increase in liver disease incidence observed in many countries is to a certain extent due to the intensified use of DDT and other organochloric insecticides.

Investigations conducted in the toxicological laboratory of the Kiev Institute of Labour Hygiene and Occupational Diseases have shown that DDT, chlorindane, hexachlorane, heptachlor and other organochloric preparations, even when taken into the organism in small quantities, accumulate in it and ofterwards give rise to various diseases. The investigations of the Ukrainian Institute of Nutrition have shown that, if a plant is treated with DDT during the period of fructification, the preparation is retained for a long time in the fruits. When milch cows are given repeated treatment to combat blood-sucking insects, DDT is eliminated in the milk during a period of over three months in quantities endangering the health of people consuming the milk. DDT does not break down under natural conditions or as a result of cooking. On the basis of the results obtained in these investigations, the State Sanitary Inspection of the U.S.S.R. has adopted an enactment prohibiting the treatment of plants with DDT during the period of fructification and providing for other restrictions. 